\title{
LEGAL ENVIRONMENT FOR ORGANIC PRODUCTION IN THE EU AND UKRAINE PPRÁVNE PROSTREDIE PRE EKOLOGICKÚ PRODUKCIU V EÚ A NA UKRAJINE
}

\author{
Kateryna ZELENSKA*
}

\section{International Disciplines on Private Standards in Agriculture}

The rise of consumers' concerns about the food safety and decrease of credibility of food safety agencies triggered a rapid growth in number and scope of private food standards which require higher products' quality and more traceability within food chains ${ }^{(1)}$. Private standards, in general, are deemed to reduce trade costs and to diminish impact of tariff barriers, but they tend to create quality access barriers, which are usually not attainable to small producers ${ }^{(2)}$.

Art. 13 of the WTO Agreement on Sanitary and Phytosanitary Measures (SPS) responds to the concerns about possible non-tariff restrictions associated with private food standards. This provision envisages state responsibility for

(1) See Josling T. Private Standards and Trade. In: McMahon J. A.; Desta M.G. (eds.) Research Handbook on the WTO Agreement on Agriculture: New and Emerging Issues in International Trade Law, Cheltenham, 2012, pp. 202-222, p. 205.

2) Ibid. p. 211

\section{Abstract (EN)}

Agricultural exporters tend to enter into contracts containing quality or standard clauses. These provisions may refer to either international public standards or standards set by private bodies. The second are usually more dynamic and thereby may respond to the consumers' demand more quickly. However, high participation costs may exclude a large share of producers from private standards schemes. The state may pick certain socially desirable private standards and evolve them to the public regulation, as it was the case of the rules on organic farming in the EU. The government may introduce aid to encourage all interested actors to participate in the scheme, although the policy space left for the government to do so is limited by the WTO disciplines for domestic support.

\section{Keywords (EN)}

DCFTA, equivalency procedure, organic agriculture, private standards, WTO Agreement on Agriculture observance of all obligations under the WTO SPS Agreement due to the state attribution of private actors' activities in this sector. WTO members are to take "reasonable measures" to ensure that non-governmental entities comply with the SPS Agreement. Correspondingly, governments shall not promote activities, which are directly or indirectly inconsistent with the WTO SPS disciplines.

Differently from the WTO law, voluntary certification of foodstuffs and agricultural products schemes are considered as a technical barrier to trade (TBT) in the $\mathrm{EU}^{(3)}$. However, this distinction should not have any major impact on EU multilateral obligations inasmuch as Art. 3.1. of the WTO TBT Agreement also requires WTO members to take reasonable measures to ensure compliance of private parties' activities with the national treatment regime and proportionality to a legitimate objective required by Art. 2 of the TBT Agreement. Legitimate objective in the sense of Art. 2.2. of

3 Commission Communication "EU best practice guidelines for voluntary certification schemes for agricultural products and foodstuffs" (2010/C 341/04), para. 6.5 .

\section{Abstrakt (SK)}

Polnohospodárski vývozcovia majú tendenciu uzatvárat' zmluvy, ktoré obsahujú ustanovenia 0 kvalite alebo štandardoch. Tieto ustanovenia sa môžu týkat' bud" medzinárodných verejných štandardov alebo štandardov stanovených súkromnými subjektmi. Druhý spomenutý typ štandardov je spravidla dynamickejší, a teda schopný rýchlejšie reagovat' na dopyt spotrebitelov. Avšak v dôsledku vysokých participatívnych nákladov môže byt' vel'ká čast' producentov vylúčená z týchto schém. Štát môže vybrat' niektoré spoločensky žiaduce súkromné štandardy a na ich základe vytvorit’ verejné ustanovenia, ako tomu bolo v prípade pravidiel týkajúcich sa ekologického ponohospodárstva v EÚ. Vláda môže zaviest' pomoc na podporu participácie všetkých zúčastnených aktérov, avšak politický priestor ponechaný pre vládne zásahy je obmedzený pravidlami WTO.

\section{Klúčové slová (SK)}

DCFTA, ekvivalentný postup, ekologické polnohospodárstvo, súkromné normy, dohody WTO o polnohospodárstve

\footnotetext{
* University of Bremen, Germany
} 
the TBT Agreement may include protection of human health or safety, animal or plant life or health, or the environment.

The two approaches basically observe the same problem from different points of view, but both are predominantly directed to discipline importing states. Apparently, it would be careless of exporters to rely on the soft regulation of Art. 13 of the SPS Agreement and Art. 3.1. of the TBT Agreement. It could be rather recommended to promote the compliance with the standards set by their importing partners. At the same time, governments could be interested in supporting the most widely spread and socially desired private standards or those that may have potential to be transposed into the public domain. One of the best examples of this approach may be attitude to organic agricultural production.

\section{What is organic production?}

Organic production is defined within European regulation as agricultural and food production based on best environmental practices, and the use of natural substances and processes $^{(4)}$. The EU recognizes the dual societal role of organic farming for supply of high quality food (to be governed by market rules) and for delivery of public goods by organic land management (to be determined by the society) ${ }^{(5)}$. This approach intends to integrate EU organic farming into the multifunctionality concept of agriculture. At the same time, the sustainability issue could be impaired by the economic reasoning, as the former is not to hinder functioning of the common market rules and fair competition ${ }^{(6)}$.

The starting point of EU regulation on organic farming ensued in the 1990s in response to a public demand for quality food. Later on, the Fischler reform integrated the organic farming priority into the Rural Development Regulation. In the course of the recent CAP reform, a separate support measure for organic farming was introduced within the rural development pillar ${ }^{(7)}$. Thus, Art. 29 of Council and Parliament Regulation No 1305/2013 foresees direct per hectare payments to active farmers for converting to or maintaining of organic farming. The provision is shaped to comply with the disciplines of para. 11 of Annex 2 of the WTO Agreement on Agriculture, which should excuse the support measure from the WTO disciplines as the "green" investment subsidy. First, the time of support is limited (Art. 29(3) of Council and Parliament Regulation No. 1305/2013 comparing to para. 11(d) of Annex 2 of the WTO Agreement on Agriculture). Second, the aid amount is calculated as a "compensation for all or part of the additional costs and income foregone resulting from the commitments made" (Art. 29(4)-(5) of Council and Parliament Regulation No. 1305/2013 and para. 11(f) of Annex 2 of the WTO Agreement on Agriculture). Being non-

(4) Rec. 1 of Council Regulation No. 834/2007.

(5) Communication from the Commission to the Council and the European Parliament "European Action Plan for Organic Food and Farming" COM(2004)415 final of 10.6.2004, p. 2.

(6) Art. 1(1) of Council Regulation No. 834/2007.

(7) Nowadays organic farming is included into the priority list of Annex IV to Council and Parliament Regulation No. 1305/2013 (earlier Art. 16a of Council Regulation No. 1698/2005). Art. 16 and 29 of Council and Parliament Regulation No. 1305/2013. related to type and volume of production, the aid should be decoupled, but the active farmer requirement may raise concerns under para. 11(e) of Annex 2 of the WTO Agreement on Agriculture. That provision excludes the conformity with the scheme payments that mandate or designate agricultural production.

The EU current rules cover all stages of production and distribution of organic foodstuffs. Organic production is not recognized at the product level, but at the production unit level. Normally the entire agricultural holding shall be managed in conformity with the organic production requirements, although the split in organic and non-organic production within one unit may be possible under conditions ${ }^{(8)}$. The compliance with the separation principle, i.e. division of organic production from conventional and biotech production, is compulsory at all stages of production and must be confirmed through labelling of organic production ${ }^{(9)}$. The accomplishment of the EU general regulatory framework established by Council Regulation No 834/2007 is still in progress as production standards for single sectors are being elaborated.

Control systems for organic production fall within the competence of the Member States that are required to publish details about their certified operators ${ }^{(10)}$. Seeing the potential to relieve the government, the EU legislator makes a distinction between "competent authority" who is in charge for organization of official controls, "control authority", delegated to pursue inspection and certification in the field of organic production, and "control body", an independent private third party carrying out corresponding inspection and certification $^{(11)}$. Thereby the EU authorizes delegation of control functions to private actors.

\section{Requirements for organic imports to the $\mathrm{EU}$}

It may be evinced that the process of legitimization of organic farming methods in the EU contributed to quick development of organic agriculture by creating incentives for farmers to shift their production to the sector. However, the domestic supply does not appear to be sufficient seeing as an increasing demand on healthy food in the EU stimulates importation of organic agricultural goods. Nowadays third countries' organic producers may be recognized by means of the equivalency procedure as set out in Art. 33 of Council Regulation No. 834/2007. Equivalency shall mean in this context capability of "meeting the same objectives and principles by applying rules which ensure the same level of assurance of conformity" as per Art. 2(1)(x) of Council Regulation No. 834/2007.

The prerequisites for the placement of an organic product on the EU market is compliance with the EU provisions on general principles, production rules, and labelling of organic

(8) Art. 11, 17 and 37 of Council Regulation No. 834/2007.

(9) Art. 18(1), 19(1), 22-26 of Council Regulation No. 834/2007; Commission Regulation No. 889/2008.

(10) Art. 27(1) of Council Regulation No. 834/2007; Commission Implementing Regulation No. 426/2011.

(11) Art. 2(1)(n),(o) and (p) of Council Regulation No. 834/2007. 
production; control over import operators, and provision of documentary evidence to ensure traceability ${ }^{(12)}$. Thus, importation of organic agricultural goods is basically allowed under condition of prior notification by an importer and the sufficient level of control ${ }^{(13)}$. The control procedure may take three forms:

- recognition of an "equivalent country";

- recognition of an "equivalent control body" (control in exporting country);

- import authorization (control in importing country) $)^{(14)}$.

To date, only a bunch of importing countries are included into the list of countries with the recognized control systems ${ }^{(15)}$. They are mostly leading agricultural exporters like Australia, Canada, New Zealand, and Switzerland. To date, Ukraine is not in the list. However, the list of the control bodies and authorities recognized for the purpose of equivalence mentions several private control bodies, which are certified to control Ukrainian agricultural production, mostly unprocessed plant products ${ }^{(16)}$.

\section{Ukraine's Potential in Organic Production}

Vast land areas that may be used in agriculture, a relative low level of industrialization along with a moderate use of fertilizers may suggest enormous potential for organic agriculture in Ukraine. Nonetheless, sustainable production per se is not sufficient for recognition of the organic status. In essence, control systems make agricultural production organic. To date certified organic production is very rare in Ukraine. This may be explained by the fact that before October 2013 there was no legal base for organic agriculture, i.e. the certification of production units used to be governed exclusively by private standards ${ }^{(17)}$. The recent Law on Organic Production, although largely concentrated on state regulation aspects, created a general framework for further legislative development ${ }^{(18)}$.

Meanwhile, under the EU-Ukraine DCFTA, the legal approximation with the EU basic organic regulation will become mandatory for Ukraine. Annex XXXVII(2) to the EUUkraine DCFTA requires legal approximation of Ukrainian regulation with Council Regulation No. 834/2007, Commis-

${ }^{(12)}$ Art. 29(1) and 32(1)(a),(b),(c) of Council Regulation No. $834 / 2007$.

(13) Art. 28 and rec. 33 of Council Regulation No. 834/2007.

(14) Art. 32 seq. of Council Regulation No. 834/2007.

(15) Annex III and the procedure set in Art. 7-8 of Commission Regulation No. 1235/2008.

(16) See Annex IV and Art. 10-11 of Commission Regulation No. 1235/2008.

(17) According to Ukrainian law, where no respective legal rules are adopted, certification must be performed voluntary in accordance to the procedure agreed in the contract between the applicant and the certification body. Art. 17 of Law No. 2406-III of 17.5.2001.

(18) Law on Production and Circulation of Organic Production No. 425-VII of 3.9.2013 provides only the general rules for organic production (Art. 16-23). Further detailed rules on production for each sector are to be adopted later (Art. 14). sion Regulation No. 889/2008 and Commission Regulation No. 1235/2008. As for now, the Law on Organic Production is in line with Council Regulation No 834/2007 for:

- the definition of organic production ${ }^{(19)}$;

- the principles of production ${ }^{(20)}$;

- implementation of separation principle (21);

- basics for conversion and parallel production ${ }^{(22)}$.

Since production standards have not been drafted yet, the procedure of assessment and certification as laid down in Art. 23-25 of Law No. 425-VII cannot be assessed in its potential equivalence to the EU norms.

Given the fact that organic regulation normally targets small and middle-scale producers who tend to have financial constraints and whose conversion to organic production is largely conditional on investment on a farm level, some governmental support may be desirable. There are basically two approaches that may be taken in this context. The first way would be the launch of direct payment schemes, e.g. on the model of ecological payments maintained in Switzerland or "green" payments in the EU after 2014. Basically, this kind of direct support should be excused from the WTO disciplines on distortive domestic support pursuant to para. 6 of Annex 2 of the WTO Agreement on Agriculture. However, it is important to guarantee a decoupled character of the payments, thus, steering the type of eligible production will not be permitted. The second way may be integration of organic support into the aid schemes for meeting standards. The new EU aid instrument for organic farming may also be taken into account.

\section{Conclusion}

Agricultural growth could be attained both by a surge of physical production and by improving the quality of agricultural products and herewith to add to their value. Promotion of organic (sustainable) farming is supposed to be one of the best means within the second approach. Moreover, organic farming is also considered to be much more environmentally friendly in comparison to conventional agriculture. In fact, the concept of organic agriculture is nothing else but a switch from monoculture-based production to small-scale production. The abovementioned could justify government's support for this market segment.

The EU regulation on organic agriculture should be become a reference point for Ukrainian rule maker in course of the implementation of the EU-Ukraine DCFTA. Despite some open questions laid down in this article, the incumbent EU support instrument for organic agricultural production may be recommended as the most promising approximation mark.

(19) Art. 1(1) of Law No. 425-VII and rec. 1 of Council Regulation No. $834 / 2007$.

(20) Art.4 of Law No. 425-VII and Art. 4 of Council Regulation No. $834 / 2007$.

(21) Art. 31 of Law No. 425-VII and Art. 17(1) and 18(1) of Council Regulation No. 834/2007.

(22) Art.30 of Law No. 425-VII and Art. 17 of Council Regulation N $834 / 2007$. 


\section{References}

1. Commission Communication "EU best practice guidelines for voluntary certification schemes for agricultural products and foodstuffs" (2010/C 341/04), para. 6.5.

2. Communication from the Commission to the Council and the European Parliament "European Action Plan for Organic Food and Farming" COM(2004)415 final of 10.6.2004, p. 2.

3. Commission Regulation No. 889/2008.

4. Commission Regulation No. 1235/2008.

5. Commission Implementing Regulation No. 426/2011.

6. Council Regulation No. 834/2007.

7. Council and Parliament Regulation No. 1305/2013 (earlier Art. 16a of Council Regulation No. 1698/2005). Art. 16 and 29 of Council and Parliament Regulation No. 1305/2013.
8. JOSLING, T. Private Standards and Trade. In: McMAHON J.A.; DESTA M.G. (eds.) Research Handbook on the WTO Agreement on Agriculture: New and Emerging Issues in International Trade Law, Cheltenham, 2012, pp. 202-222, p. 205.

9. Law No. 2406-III of 17.5.2001

10. Law on Production and Circulation of Organic Production No. 425-VII of 3.9.2013 provides only the general rules for organic production (Art. 16-23)

\section{Contact address/ Kontaktná adresa}

\section{Kateryna Zelenska, LL.M.}

accomplished her doctoral studies at the University of Bremen (Germany), email: kateryna.zelenska@gmx.de 